\title{
STRATEGI BADAN KANTOR PERTANAHAN KABUPATEN LOMBOK TENGAH DALAM MENANGGULANGI SERTIFIKAT GANDA
}

\author{
Lalu Muhammad Syukran', Novia Suhastini² \\ Ilmu Pemerintahan Universitas Muhammadiyah Mataram \\ Email: noviasuhastini@ymail.com
}

\begin{abstract}
ABSTRAK
Adanya berbagai inovasi mengenai pelayanan telah banyak dilakukan oleh sebagian besar instansi publik. Hal ini dilakukan sebagai salah satu upaya untuk mewujudkan kualitas pelayanan kepada masyarakat yang lebih baik, mudah serta terjangkau. Salah satu bentuk pelayanan publik yang diberikan oleh pemerintah adalah pelayanan dalam penerbitan sertifikat tanah. Adanya pertambahan jumlah penduduk tiap tahunnya, namun tak dapat diiringi dengan pertambahan luas tanah memungkinkan setiap orang berupaya untuk memiliki dan menguasai tanah. Tidak jarang ditemukan adanya sertifikat tanah ganda yang disebabkan oleh lemahnya pengawasan terhadap penerbitan sertifikat. Metode penelitian yang digunakan dalam penelitian ini adalah metode kualitatif deskriptif deskriptif yaitu untuk mengetahui atau menggmbarkan kenyataan dari kejadian yang diteliti sehingga memudahkan penulis untuk mendapatkan data yang objektif dalam rangka mengetahui strategi Kantor Pertanahan Kabupaten Lombok Tengah dalam menanggulangi sertifikat ganda. Tehnik pengumpulan data menggunakan observasi, wawancara dan dokumentasi serta analisis dokumen yang di dapatkan di lokasi penelitian. Adapun strategi yang dilakukan Kantor Pertanahan Kabupaten Lombok Tengah dalam menanggulangi sertifikat ganda diantaranya adalah menelaah dan mengelolah data perkara di bidang pertanahan, menampung gugatan-gugatan, menyiapkan bahan memori jawaban, menyiapkan memori banding, memori/kontra memori kasasi, memori/kontra memori peninjauan kasasi atas perkara yang diajukan melalui peradilan terhadap perorangan dan badan hukum yang merugikan negara, mengumpulkan data masalah dan sengketa pertanahan, menelaah dan menyiapkan konsep keputusan mengenai penyelesaian sengketa atas tanah serta menelaah dan menyiapkan konsep keputusan pembatalan hak atas tanah yang cacat administrasi dan berdasarkan kekuatan putusan peradilan.
\end{abstract}

Kata Kunci : Strategi, Menanggulangi, Sertifikat Ganda.

\section{LATARA BELAKANG}

Pelayanan publik saat ini menjadi isu kebijakan yang semakin strategis Karena perbaikan pelayanan publik di Indonesia cenderung "berjalan di tempat" sementara disisi lain, implikasinya sangatlah luas mempengaruhi kehidupan ekonomi, politik, sosial, budaya dan lainnya. Dalam kehidupan politik, buruknya pelayanan publik mendorong munculnya krisis kepercayaan masyarakat pada pemerintah yang teraktualisasi dalam bentuk dan demonstrasi yang tak terkontrol. Sementara itu dalam bidang sosial, pelayanan publik yang buruk ternyata mengakibatkan terganggunya psikologi masyarakat yang kian apatis terhadap pemerintah dan sesama. Akibatnya dapat terlihat melalui berbagai kerusuhan dan tindakan anarkisme diberbagai daerah. Oleh karena itulah, perbaikan sistem pelayanan publik secara berkesinambungan dan terintegrasi sesuai dengan peraturan perundang-undangan sangat mutlak dilakukan untuk mencapai tujuan pelayanan yang efektif (Sinambela : 2006).
Pemerintah selaku penyedia dan penyelenggara pelayanan harus mampu untuk memberi kepuasan ke pada masyarakat karena sudah menjadi tugas pemerintah dalam pelayanan publik. Mengingat setiap masyarakat memiliki karakter yang berbeda-beda dalam menanggapi palayanan yang diberikan oleh pemerintah dan mengArtikan kepuasan pelayanan yang berbeda pula. Maka dari itu, pemerintah harus mempunyai konsep strategi dalam menangani berbagai persepsi masyarakat tentang pelayanan yang diberikan oleh penyelenggaran pelayanan publik.

Sebagaimana dalam UUD Nomor 25 tahun 2009 Pasal 1 ayat 1 menjelaskan bahwa "pelayanan publik adalah kegiatan atau rangkaian kegiatan dalam rangka pemenuhan kebutuhan pelayanan sesuai dengan peraturan perundang-undangan bagi setiap warga negara dan penduduk atas barang, jasa, dan/atau pelayanan administratif yang disediakan oleh penyelenggara pelayanan publik". Sementara berdasarkan Kepmen PAN No. 58 tahun 2002 (Pasolong : 2008), ada 3 bentuk pelayanan yang diberikan kepada masyarakat dapat dibedakan dalam beberapa jenis pelayanan, yaitu: 
Pelayanan administratif, Pelayanan barang, Pelayanan jasa.

Semua jenis pelayanan tersebut disediakan dan diberikan kepada masyarakat oleh aparatur pemerintah, baik aparatur yang berada di pusat maupun di daerah, tetapi secara umum belum banyak memuaskan masyarakat. Hal ini di kerenakan pelayanan yang diberikan terlalu Berbelit-belit dengan alasan tidak sesuai prosedur, banyaknya biaya pungutan, dan waktu yang sangat lama, sehingga pelayanan yang diberikan cenderung tidak efektif dan efisien (Sinambela : 2006).

Adanya berbagai inovasi mengenai pelayanan telah banyak dilakukan oleh sebagian besar instansi publik. Hal ini dilakukan sebagai salah satu upaya untuk mewujudkan kualitas pelayanan kepada masyarakat yang lebih baik, mudah serta terjangkau. Dan juga sebagai jawaban kepercayaan yang telah diberikan oleh masyarakat terhadap kinerja dari birokrasi pelayanan publik yang notabene selama ini mendapatkan "image" kurang memuaskan dari sebagian besar kalangan masyarakat yang mengurus pelayanan baik itu pelayanan perizinan maupun pelayanan non perizinan. Untuk mewujudkan hal tersebut, berbagai kebijakan, keputusan dan sederatan formulasi/inovasi baru pun digulirkan dari berbagai instansi publik. (Sinambela : 2006)

Salah satu bentuk pelayanan publik yang diberikan oleh pemerintah adalah pelayanan dalam penerbitan sertifikat tanah. Tanah merupakan suatu benda yang dapat memenuhi kebutuhan dasar hidup manusia. Dapat dikatakan, hampir semua kegiatan hidup manusia dan makhluk hidup lainnya berhubungan dengan tanah. Setiap orang memerlukan tanah tidak hanya untuk hidupnya, tetapi pada saat meninggal pun manusia membutuhkan tanah guna tempat penguburannya. Manusia selalu berhubungan dengan tanah, Karena pentingnya tanah bagi kehidupan, manusia selalu berusaha untuk memiliki dan menguasai tanah. Penguasaan tanah diupayakan semaksimal mungkin untuk dapat meningkatkan kesejahteraan hidupnya. Adanya pertambahan jumlah penduduk tiap tahunnya, namun tak dapat diiringi dengan pertambahan luas tanah memungkinkan setiap orang berupaya untuk memiliki dan menguasai tanah. Dengan demikian muncul berbagai upaya dilakukan oleh manusia untuk dapat memperoleh hak atas tanah dan tentunya mempertahankannya juga dari pihak lain.
Secara filosofis, hak milik atas tanah ini berarti bahwa setiap orang yang memiliki hak milik atas tanah tersebut memilik hak untuk menggarap dan mengusahakan tanahnya serta mengalihkan tanahnya kepada orang lain. Selain itu pula, secara filosofis, tanah yang sifatnya sangat penting bagi kehidupan seseorang yang digunakan untuk berbagai hal, dengan adanya hak milik tersebut, seseorang dapat mempertahankan hak atas tanahnya jika dikemudian hari terjadi sengketa, konflik maupun masalah-masalah yang timbul dalam hal mempersoalkan eksistensi tanahnya tentunya dengan memiliki hak yang jelas guna memperoleh kepastian hukum atas haknya tersebut.

Namun, pemahaman hak milik atas tanah secara filosofi tidak bisa di batasi demikian, pemberian sifat ini tidak berarti bahwa hak itu merupakan hak yang mutlak, tak terbatas dan tidak dapat diganggu-gugat. Kata turuntemurun berarti bahwa hak milik atas tanah tidak hanya berlangsung selama hidup pemegang hak, akan tetapi apabila terjadi peristiwa hukum yaitu dengan meninggalnya pemegang hak dapat dilanjutkan oleh ahli warisnya. Kata terkuat berarti bahwa hak milik atas tanah dapat dibebani hak atas tanah lainnya, misalnya dibebani dengan Hak Guna Bangunan, Hak Pakai, dan hak lainnya.

Salah satu upaya dalam rangka menjamin kepastian hak dan kepastian hukum atas tanah baik itu hak milik maupun hak-hak lainnya, Undang-Undang Pokok Agraria (UUPA) telah menggariskan adanya keharusan untuk melaksanakan pendaftaran tanah di seluruh Indonesia, sebagaimana diamanatkan Pasal 19 UUPA. Ketentuan dalam Pasal 19 UUPA tersebut merupakan ketentuan yang ditujukan kepada pemerintah untuk menyelenggarakan pendaftaran tanah di seluruh Indonesia, yang sekaligus juga merupakan dasar hukum bagi pelaksanaan pendaftaran tanah dalam rangka memperoleh surat tanda bukti hak atas tanah yang berlaku sebagai alat pembuktian yang kuat. Untuk menindaklanjuti hal tersebut, telah dikeluarkan Peraturan Pemerintah Nomor 24 Tahun 1997 Tentang Pendaftaran Tanah, sebagai penyempurnaan dari Peraturan Pemerintah sebelumnya.

Dalam penerbitan sertifikat diperlukan suatu proses yang melibatkan pihak pemohon, para pemilik tanah yang bersebelahan, Pamong Desa maupun pihak instansi yang terkait untuk memperoleh penjelasan dan surat-surat sebagai alas hak yang berhubungan dengan permohonan 
sertifikat tersebut. Penjelasan baik lisan maupun tertulis dari pihak terkait memiliki peluang untuk terjadinya pemalsuan, daluwarsa bahkan adakalanya tidak benar atau fiktif sehingga timbul sertifikat cacat hukum ( Ali Achmad Chomzah : 2003). Sekarang dalam praktek tidak jarang terjadi beredarnya sertifikat palsu,sertifikat asli tetapi palsu atau sertifikat ganda di masyarakat sehingga pemegang hak atas tanah perlu mencari informasi tentang kebenaran datafisik dan data yuridis yang tertera dalam sertifikat tersebut di Kantor Pertanahan setempat. Pada umumnya masalah baru muncul dan diketahui terjadi penerbitan sertifikat ganda. Sertifikat Ganda adalah sertifikat-sertifikat yang menguraikan satu bidang tanah yang sama. Jadi dengan demikian satu bidang tanah diuraikan dengan 2 (dua) sertifikat atau lebih yang berlainan datanya. Hal semacam ini disebut pula "Sertifikat Tumpang Tindih (overlapping)", baik tumpang tindih seluruh bidang maupun tumpang tindih sebagian dari tanah tersebut.

Sertifikat ganda sering terjadi di wilayahwilayah yang sebagian besar masih kosong, belum adanya pembangunan yang pesat dan di daerah perbatasan kota dimana untuk lokasi tersebut belum tersedianya secara menyeluruh peta-peta pendaftaran tanahnya sebagaimana yang terjadi di wilayah Kabupaten Lombok Tengah, Nusa Tenggara Barat. Secara umum, ada beberapa hal yang menyebabkan terjadiya sertifikat ganda di Kabupaten Lombok Tengah yakni Adanya surat bukti atau pengakuan hak dibelakang hari terbukti mengandung ketidakbenaran, kepalsuan atau sudah tidak berlaku lagi serta adanya kasus penerbitan lebih dari satu sertifikat atas sebidang tanah dapat pula terjadi atas tanah warisan. Latar belakang kasus tersebut adalah sengketa harta warisan yaitu oleh pemilik sebelum meninggalnya telah dijual kepada pihak lain (tidak diketahui oleh anak-anaknya) dan telah diterbitkan sertifikat atas nama pembeli, dan kemudian para ahli warisnya menyertifikatkan tanah yang sama, sehingga mengakibatkan terjadi sertifikat ganda, karena sertifikat terdahulu ternyata belum dipetakan.

Akibat tidak adanya jaminan kepastian hukum yang ditimbulkan karna adanya sertifikat ganda khususnya bagi pemegang sah hak atas tanah, maka hal ini tentu akan berdampak pada suatu gejala adanya perbedaan antara harapan (dassollen) dengan kenyataan lapangannya (das sein) dalam aspek perlindungan hukum dari penyelenggaraan pendaftaran tanah di Indonesia khususnya di wilayah Kabupaten Lombok
Tengah yang tentunya akan mengakibatkan konflik yang berkepanjangan antar para pihak yang bersengketa dan tentunya hal ini sama sekali tidak sesuai dengan tujuan dari pendaftaran tanah sebagaiamana ketentuan pasal 3 ayat (1) PP No.24 Tahun 1997 yakni memberikan kepastian hukum dan perlindungan hukum kepada pemegang hak atas suatu bidang tanah agar dengan mudah dapat membuktikan dirinya sebagai pemegang hak yang bersangkutan. Oleh sebab itu, sangat dibutuhkan peran aktif pelayanan publik terutama oleh Badan Pertanahan Kabupaten Lombok Tengah Dalam merumuskan strategi Menanggulangi sertifikat Ganda di wilayah tersebut.

\section{KERANGKA TEORITIK}

\section{Pengertian Strategi}

Menurut Chandler dalam Triton PB (2007:16), Strategi adalah penetapan tujuan dasar jangka panjang dan sasaran perusahaan, dan penerapan serangkaian tindakan, serta alokasi sumber daya penting untuk melaksanakan sasaran ini. Menurut Argyris, Mintzberg, dkk dalam (Rangkuti 1997:22) menyatakan bahwa strategi merupakan respon secara terus-menerus maupun adaptif terhadap peluang dan ancaman eksternal serta kekuatan dan kelemahan internal yang dapat mempengaruhi organisasi. dengan lingkungan yang dihadapinya, kesemuanya menjamin agar tujuan perusahaan tercapai.

Menurut Lawrence R. Jauch \& W.F Glueck dalam (Iwan Purwanto 2007:21), strategi adalah rencana yang disatukan, menyeluruh dan terpadu yang mengkaitkan keunggulan strategi perusahaan dengan tantangan lingkungan dan yang dapat dirancang untuk memastikan tujuan utama perusahaan dapat dicapai melalui pelaksanaan yang tepat oleh perusahaan. Menurut Mintzberg yang dikutip dalam (Jemsly Hutabarat \& Martani Huseini 2006:18) mengemukakan 5P yang sama artinya dengan strategi, yaitu:

\section{a. Strategi adalah Perencanaan (Plan)}

Konsep strategi tidak lepas dari aspek perencanaan, arahan atau acuan gerak langkah perusahaan untuk mencapai suatu tujuan di masa depan. Akan tetapi, tidak selamanya strategi adalah perencanaan ke masa depan yang belum dilaksanakan. Strategi juga menyangkut segala sesuatu yang telah dilakukan sebelumnya.

\section{b. Strategi adalah Pola (Platern)}

Strategi adalah pola (strategy is patern), yang selanjutnya disebut sebagai intended 
strategy, karena belum terlaksana dan berorientasi ke masa depan. Atau disebut juga sebagai realized strategy karena telah dilakukan oleh perusahaan.

\section{c. Strategi adalah Posisi (Position)}

Yaitu memposisikan produk tertentu ke pasar tertentu yang dituju. Strategi sebagai posisi cenderung melihat ke bawah, yaitu ke suatu titik bidik di mana produk tertentu bertemu dengan pelanggan, dan melihat ke luar yaitu meninjau berbagai aspek lingkungan eksternal.

\section{d. Strategi adalah Perspektif (Perspektif)}

Jika dalam arti Pola dan Posisi cenderung melihat ke bawah dan ke luar, maka sebaliknya dalam Perspektif cenderung lebih melihat ke dalam yaitu ke dalam organisasi, dan ke atas yaitu melihat grand vision dari perusahaan.

\section{e. Strategi adalah Permainan (Play)}

Dalan arti ini, strategi adalah suatu manuver tertentu untuk memperdaya lawan atau pesaing. Suatu merek misalnya meluncurkan merek kedua agar posisinya tetap kukuh dan tidak tersentuh, karena merek-merek pesaing akan sibuk berperang melawan merek kedua tadi.

\section{Jenis-jenis Strategi}

Mintzberg dan Waters dalam (Fajar Apriani 2003:156) mengklasifikasikan delapan jenis strategi yaitu :

\section{a. Strategi yang terencana}

Merupakan keluaran dari perencanaan formal dirumuskan dan didistribusikan oleh manajemen tingkat diatas, yang menjaga kesinambungan implementasi dalam lingkungan yang terkendali melalui sarana prosedur pengendalian formal.

\section{b. Startegi intrapreneur}

Merupakan keluaran dari visi yang terpusat, yang kadang kala berasal dari gagasan satu atau beberapa manajer dan yang dapat disesuaikan dengan peluang-peluang baru. Pemimpin atau manajer tersebut melaksanakan pengendalian pribadi terhadap organisasi.

\section{c. Strategi ideology}

Merupakan keluaran dari nilai-nilai kemasyarakatan yang secara normatif diperkuat dan dikendalikan melalui sosialisasi dan indoktrinasi. Ada kalanya organisasi bereaksi secara proaktif berkenaan dengan perubahan lingkungan.

\section{d. Strategi payung}

Merupakan keluaran dari suasana penuh keterbatasan, dimana manajemen tingkat atas hanya mempunyai wewenang terbatas untuk mengendalikan organisasi, mendefimisikan strategi aturan main, yang hanya disimpulkan dari perkiraan-perkiraan sasaran yang bersifat umum. Ciri khasnya dapat diterapkan pada lingkungan kompleks yang sulit untuk diramalkan.

\section{e. Strategi proses}

Merupakan keluaran dari suatu proses, dimana manajemen tingkat atas mengawasi semua proses strategi tersebut (mencari anggota, penataan struktur dan mendelegasikan elemenelemennya pada pelaku lain dalam organisasi).

\section{f. Strategi parsial}

dimana para pelaku dalam organisasi mengembangkan sendiri pola-pola tertentu dalam aktivitas mereka dikarenakan ketiadaan suatu strategi terpusat atau keadaan situasi yang berlawanan dengan ketentuan terpusat yang berlaku.

\section{g. Strategi consensus}

Muncul dari kesepakatan melalui upaya saling pengertian, dimana para pelaku organisasi saling menyesuaikan pola mereka kembangkan, dikarenakan oleh ketiadaan ketentuan terpusat atau yang lebih mengikat.

\section{h. Strategi pendukung}

Merupakan keluaran dari dinamika lingkungan, dimana lingkungan mendikte polapola tertentu dalam aktivitas organisasi. Lingkungan menggiring strategi organisasi atau secara tidak langsung membatasi melalui pemilihan alternatif yang berbeda.

\section{Manajemen Strategi}

Istilah perencanaan strategi pertama kali muncul pada 1950-an danmenjadi sangat popular antara pertengahan 1960-an dan pertengahan 1970-an. Fred R. David (2010:5) Manajemen strategi dapat didefinisikan sebagai seni mencapai tujuannya. Sebagaimana disiratkan oleh definisi ini, manajemen strategi berfokus pada usaha untuk mengintegrasikan manajemen, pemasaran, keuangan/akuntasi, produksi/operasi, penelitian dan pengembangan, dan sistem informasi 
komputer untuk mencapai keberhasilan organisasi.

Thompson dan Martin dalam AB Susanto (2014:3), Manajemen strategi adalah proses dengan mana sebuah organisasi menentukan tingkat tujuan, sasaran, dan hasrat pencapaian, memutuskan tindakan untuk mencapainya dalam skala waktu yang tepat dalam lingkungan yang senantiasa berubah, mengimplementasikan tindakan, dan menilai kemajuan hasil.

Lawrence R. Jauch dan William F. Glueck dalam Yogi (2007:7), Manajemen strategi merupakan arus keputusan dan tindakan yang mengarahkan pengembangan suatu strategi yang efektif atau strategis untuk mencapai sasaran perusahaan. Proses manajemen strategi adalah suatu cara bagaimana suatu strategi menentukan sasaran dan membuat keputusan strategis.

\section{Konsep Sertifikat Tanah}

Dalam Undang-Undang Pokok Agraria (UUPA) dijelaskan bahwa untuk mewujudkan jaminan kepastian hukum dan kepastian hak atas tanah maka perlu dilakukan kegiatan pendaftaran oleh pemerintah sesuai dengan ketentuanketentuan yang telah diatur .Menurut PP No. 10 Tahun 1960, sertifikat tanah adalah salinan buku tanah dan surat ukur yang dijahit menjadi satu bersama-sama dengan kertas sampul yang bentuknya ditentukan oleh Menteri Agraria. Dalam PP No. 24 Tahun 1997, sertifikat tanah adalah surat tanda bukti hak sebagaimana dimaksud dalam Pasal 19 ayat (2) huruf c UUPA untuk hak atas tanah, hak atas pengelolaan, tanah wakaf, hak milik atas satuan rumah susun dan hak tanggungan yang masing-masing sudah dibukukan dalm buku tanah yang bersangkutan.”

Berdasarkan pengertian di atas, dapat kita simpulkan bahwa sertifikat tanah terdiri atas salinan buku tanah dan surat ukur yang asli dijahit menjadi sampul. Buku tanah yaitu dokumen dalam bentuk daftar yang memuat data yuridis dan data fisik suatu objek pendaftaran tanah yang sudah ada haknya. Sedangkan surat ukur adalah dokumen yang memuat data fisik suatu bidang tanah dalam bentuk peta dan uraian. Sertifikat tanah diterbitkan untuk kepentingan pemegang hak yang bersangkutan sesuai dengan data fisik dan data yuridis yang telah didaftar dalam buku tanah. Data fisik (pemetaan ) meliputi letak tanah, batas-batas tanah, luas tanah dan bangunan/tanaman yang ada diatasnya. Sedangkan data yuridis berupa status tanah (jenis haknya), subjeknya, hak-hak pihak ketiga yang membebaninya dan jika terjadi perisitiwa hukum atau perbuatan hukum, wajib didaftarkan.
Selanjutnya, sertifikat tanah hanya boleh diserahkan kepada pihak yang namanya tercantum dalam buku tanah sebagai pemegang hak atau kepada pihak yang diberikan kuasa oleh pemegang hak.

Sertifikat tanah memiliki manfaat yang sangat penting dan menguntungkan bagi setiap pihak yang memilik atau menguasai sebidang tanah. Manfaat dari setifikat tanah adalah:

a. Dengan sertifikat tanah maka dapat dibuktikan secara meyakinkan akan hak yang dimiliki atas sebidang tanah.

b. Sertifikat tanah sangat diperlukan dalam pengajuan kredit bank sebab pihak bank berpendapat bahwa sertifikat tanah adalah jaminan yang aman.

c. Bagi ahli waris, sertifikat tanah atas harga berupa tanah yang diwariskan oleh pewaris akan jaminan hak-hak yang akan diperoleh ahli waris atas tanah yang diwariskan tersebut.

d. Biasanya pada transaksi jual belii pembeli tanah akan menawar harga tanah lebih tinggi apabila tanah yang diperjual belikan telah memiliki sertifikat tanah.

e. Selain itu biasanya pula penjualan tanah yang telah bersertifikat akan lebih mudah.

\section{Pendaftaran Tanah}

Parlindungan, pendaftaran tanah berasal dari kata Cadaster (bahasa Belanda Kadaster) suatu istilah tehnis untuk suatu Record (rekaman), menunjukan kepada luas, nilai dan kepemilikan (atau lain-lain atas hak) terhadap suatu bidang tanah. Kata ini berasal dari bahasa latin "Capistratum" yang berarti suatu Register atau unit yang dibuat untuk pajak tanah Romawi. Dalam arti yang tegas, Cadastre adalah Record pada lahan-lahan, nilai dari pada tanah dan pemegang haknya dan untuk kepentingan perpajakan. Dengan demikian, Cadastre merupakan alat yang tepat yang memberikan uraian dan identifikasi dari tersebut dan juga terbagi rekaman yang berkesinambungan dari hak atas tanah (AP. Parlindungan 1991:22).

Pendaftaran tanah adalah suatu rangkaian kegiatan, yang dilakukan oleh Negara/Pemerintah secara terus-menerus dan teratur, berupa pengumpulan keterangan atau data tertentu mengenai tanah-tanah tertentu yang ada di wilayah-wilayah tertentu, pengolahan, penyimpanan dan penyajiannya bagi kepentingan rakyat, dalam rangka memberikan jaminan kepastian hukum dibidangpertanahan, termasuk penerbitan tanda bukti dan pemeliharaannya ( Boedi Harsono 1994:13). 
Suatu rangkaian kegiatan, menunjuk kepada adanya berbagai kegiatan dalam penyelenggaraan pendaftaran tanah, yang berkaitan satu dengan yang lain, berurutan menjadi satu kesatuan rangkaian yang bermuara pada tersedianya data yang diperlukan dalam rangka memberikan jaminan kepastian hukum dibidangpertanahan bagi rakyat.

Terus menerus, menunjuk kepada pelaksanaan kegiatan, yang sekali dimulai tidak akan ada akhirnya. Data yang sudah terkumpul dan tersedia selalu harus disesuaikan dengan perubahan-perubahan yang terjadi kemudian, hingga tetap sesuai dengan keadaan yang terakhir.

Teratur menunjukkan bahwa semua kegiatan harus berlandaskan peraturan perundang-undangan yang sesuai, karena hasilnya akan merupakan data bukti menurut hukum, meskipun daya kekuatan pembuktiannya tidak selalu sama dalam hukum negara-negara yang menyelenggarakan pendaftaran tanah.

Data yang dihimpun pada dasarnya meliputi 2 bidang, yaitu:

a. Data fisik mengenai tanahnya, merupakan keterangan mengenai lokasi, luas, batas-batas, serta bangunan atau bagian bangunan yang berada di atas obyek pendaftaran tanah.

b. Data yuridis mengenai tanahnya, meliputi keterangan mengenai status hukum atau status penguasaan atas obyek pendaftaran tanah, pemegang hak atau pihak yang menguasai dan pihak lain serta beban-beban lain yang membebaninya.

Wilayah, menunjukkan wialyah kesatuan administrasi pendaftaran tanah. "Tanah-tanah tertentu"menunjuk kepada kemungkinan, bahwa yang didaftarkan hanya sebagian tanah yang dipunyai dengan hak-hak yan ditunjuk. Di dalam UUPA tahun 1960 sendiri dalam pasal 19 sub (a) disebutkan bahwa pendaftaran tanah meliputi pengukuran, perpetaaan dan pembukuan tanah. Menurut Yanis Maladi, pada pokoknya unsurunsur pendaftaran tanah(kadaster) yaitu:

a. Pendaftaran atau pembukuan adalah menunjukkan luas, nilai dan pemilik bidangbidang tanah yang terletak di suatu daerah tertentu dengan menunjukkan batas-batas dari tiap-tiap bidang tanah, mencantumkan nama pemegang hak serta mencantumkan hak-hak yang terdapat di atasnya.

b. Pemetaan dan pengukuran bidang bidang tanah yang didaftarkan. c. Menjamin kepastian obyek hak atas tanah yang didaftarkan (Yanis Maladi 2008:22).

Dalam pasal 1 PP no. 24 tahun 1997 tentang Pendaftaran Tanah disebutkan bahwa: "Pendaftaaran tanah adalah rangkaian kegiatan yang dilakukan oleh Pemerintah secara terus menerus, berkesinambungan dan teratur, meliputi pengumpulan, pengolahan, pembukuan, dan penyajian serta pemeliharaan data fisik dan data yuridis, dalam bentuk peta dan daftar, mengenai bidang-bidang tanah dan satuan rumah susun, termasuk pemberian tanda bukti haknya bagi bidang-bidang tanah yang sudah ada haknya, dan hak milik atas dstusn rumah susun serta hak-hak tertentu yang membebaninya".

Apa yang dikemukakan dalam PP 24 Tahun 1997 tersebut, dituangkan kembali dalam Peraturan Menteri Agraria dan Tata Ruang/KBPN RI No. 35 tahun 2016 tentang Percepatan Pendaftaran Tanah Sistematis Lengkap pada pasal 1 angka 2. Dari pengertian tersebut menunjukkan bahwa ada berbagai macam kegiatan dalam penyelenggaraan pendaftaran tanah yang berurutan, saling berkaitan satu sama lain dan merupakan suatu kesatuan untuk memperoleh apa yang disebut sertifikat. Kegiatan pendaftaran tanah tidak hanya diadakan sekali tetapi untuk seterusnya apabila terjadi perubahan terhadap tanah maupun pemegang haknya sehingga sesuai dengan kanyataan terakhir yang ada berlandaskan peratuaran hukum yang ada.

Dalam era pembangunana dewasa ini, sasaran penting dalam pendaftaran tanah adalah mewujudkan Catur Tertib Pertanahan yakni : (Ali Ahmad Comzah 2004:15)
a. Tertib hukum pertanahan
b. Tertib administrasi pertanahan
c. Tertib penggunaan tanah
d. Tertib pemeliharaan dan lingkungan hidup.

\section{Sertipikat Ganda}

Ali Achmad Chomzah, sertipikat ganda adalah sertipikat-sertipikat yang menguraikan satu bidang tanah yang sama, dengan demikian satu bidang tanah diuraikan dalam 2 (dua) sertipikat atau lebih yang datanya berlainan (Ali Chomzah 2002:8). Penyebab lainnya dari sengketa pertanahan adalah nilai ekonomis tanah yang cukup tinggi dan tanah merupakan simbol eksistensi dan status sosial ditengah masyarakat sehingga mengakibatkan timbulnya konflik pertanahan yang vertikal dan horizontal itu.Tumpang tindihnya pengeluaran suatu 
keputusan dari instansi-instansi yang berhubungan langsung dengan pertanahan juga merupakan salah satu faktor timbulnya sengketa pertanahan termasuk timbulnya sertifikat ganda.

Sertipikat ganda berarti terjadi tumpang tindih bidang tanah, baik tumpang tindih seluruh bidang tanah maupun tumpang tindih sebagian dari bidang tanah tersebut. Hal yang demikian umumnya terjadi pada tanah yang masih kosong atau belum dibangun. Lahirnya sertipikat ganda, tidak lepas dari tindakan pejabat Kantor Pertanahan, seperti membatalkan sebuah sertipikat yang lama dan menerbitkan sertipikat yang baru untuk dan atas nama orang lain tanpa sepengetahuan pemilik yang namanya tercantum dalam sertipikat tanahyang lama. Bahkan penerbitan sertipikat yang baru dilakukan oleh pejabatKantor Pertanahan tanpa prosedur hukum.

Namun apabila terjadi sertipikat ganda, maka harus ada pembatalan dari salah satu pihak dengan memeriksa dokumen pendukung.Hal ini bisa berlangsung lama, apalagi jika terjadi gugatan sertipikat ke pengadilan, untuk meminta pembatalan oleh pihak yang merasa dirugikan. Upaya untuk mencegah terjadinya sertipikat ganda tidak ada jalan lain harus mengoptimalkan administrasi pertanahan dan pembuatan peta pendaftaran tanah. Dengan adanya peta pendaftaran tanah dan administrasi pertanahan yang baik, kesalahan penempatan letak dan batas dapat diketahui sedini mungkin. Utoyo Sutopo (1992:5), ada dua faktor penyebab terjadinya sertifikat ganda, yakni faktor ekstern dan intern.

\section{a. Faktor intern antara lain:}

1) Tidak dilaksanakannya Undang-Undang Pokok Agraria dan peraturan pelaksanaannya secara konsekuen dan bertanggungjawab disamping masih adanya orang yang berbuat untuk memperoleh keuntungan pribadi.

2) Kurang berfungsinya aparat pengawas sehingga memberikan peluang kepada aparat bawahannya untuk bertindak menyeleweng dalam arti tidak melaksanakan tugas dan tanggung jawab sesuai sumpah jabatannya.

3) Ketidaktelitian pejabat Kantor Pertanahan dalam menerbitkan sertifikat tanah yaitu dokumendokumen yang menjadi dasar bagi penerbitan sertifikat tidak diteliti dengan seksama yang mungkin saja dokumen-dokumen tersebut belum memenuhi persyaratan sebagaimana ditentukan oleh ketentuan perundang-undangan yang berlaku.

\section{b. Faktor ekstern antara lain:}

1) Masyarakat masih kurang mengetahui undangundang dan peraturan tentang pertanahan khususnya tentang prosedur pembuatan sertifikat tanah.

2) Persediaan tanah tidak seimbang dengan jumlah peminat yang memerlukan tanah.

3) Pembangunan mengakibatkan kebutuhan akan tanah semakin meningkat sedangkan persediaan tanah sangat terbatas sehingga mendorong peralihan fungsi tanah dari tanah pertanian ke non pertanian, mengakibatkan harga tanah melonjak

Dalam ketentuan peraturan perundangundangan, terjadinya sertipikat ganda merupakan salah satu akibat adanya tumpang tindih dalam penerbitan sertipikat hak atas tanah yang disebut cacat hukum administrasi. Sebagaimana terdapat dalam Pasal 107 Peraturan Menteri Agraria/ Kepala Badan Pertanahan Nasional Nomor 9 Tahun 1999 Tentang Tata Cara Pemberian dan Pembatalan Hak Atas Tanah dan Hak Pengelolaan, sertipikat hak atas tanah yang cacat hukum administratif adalah sertipikat hakatas tanah yang mengandung kesalahan antara lain sebagai berikut:

a. kesalahan prosedur

b. kesalahan penerapan peraturan perundangundangan

c. kesalahan subjek hak

d. kesalahan objek hak

e. kesalahan jenis hak

f. kesalahanperhitungan luas

g. terdapat tumpang tindih hak atas tanah

h. data yuridis dan data fisik tidak benar; atau

i. kesalahan lainnya yang bersifat administrative

\section{METODE PENELITIAN}

Pendekatan penelitian yang digunakan dalam penelitian ini adalah jenis kualitatif, Menuurt Sugiono (2014:1) yang dimaksud dengan penelitian kualitatif yaitu metode penelitian yang digunakan untuk meneliti pada kondisi obyek yang alamaiyah, dimana peneliti adalah sebagai instrumen kunci, teknik pengumpulan data secara gabungan, analisa data bersifat induktif dan dan hasil penelitian kualitatif lebih menekankan makna daripada generalisasi. Penelitian yang dilakukan hanya bersifat deskriptif yaitu untuk mengetahui atau menggambarkan kenyataan dari kejadian yang diteliti sehingga memudahkan penulis untuk mendapatkan data yang objektif dalam rangka mengetahui strategi Kantor Pertanahan 
Kabupaten Lombok Tengah dalam menanggulangi sertifikat ganda.

\section{HASIL DAN PEMBAHASA}

\section{Strategi Yang Dilakukan Kantor Pertanahan Kabupaten Lombok Tengah Dalam Menanggulangi Sertifikat Ganda}

Pelaksanaan pendaftaran tanah diatur dengan PP No 10 Tahun 1961 yang kemudian disempurnakan dengan PP No. 24 Tahun 1997 dan Peraturan Menteri Agraria/ Kepala Badan Pertanahan Nasional Nomor 3 Tahun 1997 tentang ketentuan pelaksanaan PP No 24 Tahun 1997 tentang pendaftaran tanah. Jaminan kepastian hukum hak atas tanah dapat diperoleh bagi pemegang hak dengan wajib dilakukan inventarisasi data-data yang berkenaan dengan setiap peralihannya.Terselenggaranya pendaftaran tanah secara baik merupakan dasar dan perwujudan tertib administrasi di bidang pertanahan. Untuk mencapai tertib administrasi tersebut setiap bidang tanah dan satuan rumah susun, termasuk peralihan, pembebanan dan hapusnya wajib didaftar.

Dalam pelaksanaan pendaftaran tanah, ada dua sistem pendaftaran tanah yang diterapkan di Indonesia. Menurut (Boedi Harsono 2002:76) sistem pendaftaran tanah ada 2 (dua) macam, yaitu sistem pendaftaran akta (registration of deeds) dan sistem pendaftaran hak (registration of title).Baik dalam sistem pendaftaran akta maupun sistem pendaftaran hak, setiap pemberian atau penciptaan hak baru, peralihan serta pembebanannya dengan hak lain, harus dibuktikan dengan suatu akta.Pada sistem pendaftaran akta, akta-akta itulah yang didaftarkan oleh pejabat pendaftaran tanah. Dalam sistem ini pejabatnya bersifat pasif sehingga ia tidak melakukan penyelidikan data yang tercantum dalam akta yang didaftar. Tiap kali terjadi perubahan wajib dibuatkan akta sebagai buktinya. Maka dalam sistem ini data yuridis yang diperlukan harus dicari dalam akta-akta yang bersangkutan. Untuk memperoleh data yuridis yang diperlukan harus melakukan apa yang disebut "title search" yang dapat memakan waktu lama dan biaya. Pada sistem pendaftaran hak, bukan aktanya yang didaftar, melainkan haknya yang diciptakan dan kemudian.Akta merupakan sumber datanya.Untuk pendaftaran hak dan perubahan-perubahan yang terjadi disediakan suatu daftar isian (register), atau disebut juga buku tanah. Buku tanah ini disimpan di kantor pertanahan dan terbuka untuk umum. Dalam sistem ini pejabat pendaftaran tanah bersikap aktif dan sebagai tanda bukti hak diterbitkan sertifikat yang merupakan salinan register (certificate of title).

Kewenangan tanah diselenggarakan oleh Pemerintah dalam hal ini adalah Badan Pertanahan Nasional (BPN). BPN adalah lembaga pemerintah non departemen yang mempunyai tugas di bidang pertanahan dengan unit kerja yaitu Kantor Wilayah Badan Pertanahan Nasional di Propinsi dan Kantor Pertanahan di Kota/Kabupaten. Dalam konteks tipologi, BPN membagi sengketa pertanahan dibagi menjadi sengketa penguasaan dan pemilikan, sengketa prosedur penetapan dan pendaftaran tanah, sengketa batas/letak bidang tanah, sengketa ganti rugi eks tanah partikelir, sengketa tanah ulayat, sengketa tanah obyek landreform, sengketa pengadaan tanah, dan sengketa pelaksanaan putusan (Purnadi Purbacaraka dan ridwan Halim 1985:67).

Jika dicermati, konflik pertanahan yang terjadi selama ini berdimensi luas, baik konflik horizontal maupun konflik vertikal. Konflik vertikal yang paling dominan yaitu antara masyarakat dengan masyarakat atau antara masyarakat dengan pemerintah. Misalnya salah satu kasus yang paling menonjol adalah kasus yang paling sering terjadi adalah permasalahan sertifikat ganda atau kepemilikan beberapa sertifikat pada sebuah bidang tanah.

Menurut kantor pertanahan Lombok tengah, ada dua faktor yang menyebabkan terjadinya sertifikat ganda, yakni faktor eksternal dan faktor internal :

\section{a. Faktor eksternal:}

1) Terkait dengan subyek hak, si pemilik tanah tidak jujur bahwa sertifikatnya sudah ada pemiliknya

2) Pemilik tanah tidak pernah menguasai tanah secara utuh, 
artinya si pemilik hanya memegang sertifikat tapi tidak menggarap tanahnya

3) Pada waktu dilakukan pengukuran ataupun penelitian di lapangan, pemohon dengan sengaja atau tidak sengaja menunjukkan letak tanah dan batas-batas tanah yang salah.

\section{b. Faktor internal:}

1) Perangkat desa atau orang-orang sebagai penguasa wilayah tidak tau persis terkait dengan penguasaan tanah yang mejadi sengketa

2) Pemetaaan tanah saat itu masih menggunakan data manual sehingga tidak bisa di ketahui data fisik suatu tanah.

3) Overlapping (tumpang tindih) yaitu ada dua atau lebih sertipikat yang tumpang tindih satu dengan lainnya sehingga bagian yang tumpang tindih tersebut merupakansertipikat ganda, karena sebagian tanahnya termasuk dalam sertipikat yang lain

4) Adanya surat bukti atau pengakuan hak dibelakang hari terbukti mengandung ketidakbenaran, kepalsuan atau sudah tidak berlaku lagi.

5) karena adanya pemberian hak baru oleh Kantor Pertanahan Lombok Tengah berdasarkan proses Ajudikasi, yaitu kegiatan yang dilaksanakan dalam rangka proses pendaftaran tanah untuk pertama kali, meliputi pengumpulan dan penetapan kebenaran data fisik dan yuridis mengenai satu atau beberapa obyek pendaftaran tanah untuk keperluan pendaftarannya (Pasal 1 angka 8 PP 24/1997 tentang Pendaftaran Tanah). hal ini menunjukan bahwa adanya ketidakcermatan dan ketidak telitiannya dalam memeriksa dan meneliti data-data fisik dan data yuridis baik secara langsung di lapangan maupun dalam hal penyelidikan riwayat tanah dan penilaian kebenaran alat bukti pemilikan atau penguasaan tanah melalui pengecekan warkah yang ada di Kantor Pertanahan Lombok Tengah.
Dari kedua faktor tersebut, faktor terpenting yang menyebabkan terjadinya sertipikat ganda adalah karena terjadinya cacat hukum administrasi terutama terkait dengan beberapa kekeliruan teknis dalam proses pendaftaran hak atas tanah pertamakali. Dapat dikatakan bahwa dengan munculnya sertipikat ganda, maka kedudukan sertipikat ganda harus ditinjau ulang karena tidak mungkin kedua sertifikat itu dapat berlaku. Terdapat cacat hukum dalam sertipikat ganda ini, dalam hal ini kita melihat bahwa prinsip yang diambil adalah agar berbeda daripada apa yang biasanya terjadi dengan penerbitan dari sertipikat ganda atas satu bidang tanah diterbitkan 2 (dua) sertipikat. Dalam hal terjadinya sertipikat ganda, biasa dinyatakan bahwa sertipikat yang diterbitkan lebih dahulu adalah yang sah, sedangkan yang diterbitkan kemudian adalah yang tidak mempunyai kekuatan hukum.

Untuk meminimalkan sengketa pertanahan dalam hal ini sertifikat ganda, maka dalam hal ini peran yang dilakukan BPN Lombok Tengah sebagai pelayan masyarakat antara lain adalah:

a. Menelaah dan mengelolah data untuk menyelesaikan perkara di bidang pertanahan.

b. Menampung gugatan-gugatan, menyiapkan bahan memori jawaban, menyiapkan memori banding, memori/kontra memori kasasi, Memori/kontra memori peninjauan kasasi atas perkara yang diajukan melalui peradilan terhadap perorangan dan badan hukum yang merugikan negara.

c. Mengumpulkan data masalah dan sengketa pertanahan.

d. Menelaah dan menyiapkan konsep keputusan mengenai Penyelesaian sengketa atas tanah.

e. Menelaah dan menyiapkan konsep keputusan pembatalan hak atas tanah yang cacat administrasi dan berdasarkan kekuatan putusan peradilan.

f. Mendokumentasi.

BPN Lombok Tengah juga memiliki mekanisme tertentu dalam menangani dan menyelesaikan perkara atau sengketa pertanahan dalam hal ini termasuk juga sengketa sertifikat ganda yaitu: 
a. Sengketa tanah biasanya diketahui oleh BPN dari pengaduan.

b. Pengaduan ditindaklanjuti dengan mengidentifikasikan masalah. Dipastikan apakah unsur masalah merupakan kewenangan BPN atau tidak.

c. Jika memang kewenangannya, maka BPN meneliti masalah untuk membuktikan kebenaran pengaduan serta menentukan apakah pengaduan beralasan untuk diproses lebih lanjut.

d. Jika hasil penelitian perlu ditindaklanjuti dengan pemeriksaan data fisik administrasi serta yuridis, maka kepala kantor dapat mengambil langkah berupa pencegahan mutasi (status quo).

e. Jika permasalahan bersifat strategis, maka diperlukan pembentukan beberapa unit kerja. Jika bersifat politis, sosial, dan ekonomis maka tim melibatkan institusi berupa DPR atau DPRD, departemen dalam negeri, pemerintah daerah terkait.

f. Tim akan menyusun laporan hasil penelitian untuk menjadi bahan rekomendasi penyelesaian masalah.

Dalam prakteknya, penyelesaian terhadap sengketa pertanahan bukan hanya dilakukan oleh Badan Pertanahan Nasional tetapi juga bisa diselesaikan oleh lembaga Peradilan Umum dan Peradilan Tata Usaha Negara. Jika diperadilan umum lebih menitikberatkan kepada hal-hal mengenai perdata dan pidana dalam sengketa pertanahan, lain halnya dengan peradilan tata usaha negara yang menyelesaikan sengketa pertanahan berkaitan dengan surat keputusan yang dikeluarkan oleh Badan Pertanahan Nasional atau pejabat daerah lainnya yang berkaitan dengan tanah.

Pada saat ini, kebanyakan sengketa pertanahan dalam hal ini sertifikat ganda diselesaikan melalui 3 (tiga) cara, yaitu:

\section{a. Penyelesaian secara langsung oleh pihak dengan musyawarah}

Dasar musyawarah untuk mufakat tersirat dalam pancasila sebagai dasar kehidupan bermasyarakat Indonesia dan dalam UUD 1945. Musyawarah dilakukan diluar pengadilan dengan atau tanpa mediator. Mediator biasanya dari pihak-pihak yang memiliki pengaruh misalnya Kepala Desa/Lurah, ketua adat serta pastinya Badan Pertanahan Nasional.

Dalam penyelesaian sengketa pertanahan lewat musyawarah, satu syaratnya adalah bahwa sengketa tersebut bukan berupa enentuan tentang kepemilikan atas tanah yang dapat memberikan hak atau menghilangkan hak seseorang terhadap tanah sengketa, dan diantara pihak bersengketa memiliki kekebaratan yang cukup erat serta masih menganut hukum adat setempat.

b. Melalui arbitrase dan alternative penyelesaian sengketa

Arbitrase adalah penyelesaian perkara oleh seorang atau beberapa arbiter (hakim) yang diangkat berdasarkan kesepakatan/ persetujuan para pihak dan disepakati bahwa putusan yang diambil bersifat mengikat dan final. Persyaratan utama yang harus dilakukan untuk dapat mempergunakan arbitrase sebagai penyelesaian sengketa adalah adanya kesepakatan yang dibuat dalam bentuk tertulis dan disetujui oleh para pihak. Jika telah tertulis suatu klausula arbitrase dalam kontrak atau suatu perjanjian arbitrase, dan pihak lain menghendaki menyelesaikan masalah hukumnya ke pengadilan, maka proses pengadilan harus ditunda sampai proses arbitrase tersebut diselesaikan dalam lembaga arbitrase. Dengan demikian pengadilan harus dan wajib mengakui serta menghormati wewenang dan fungsi arbiter.

\section{c. Penyelesaian sengketa melalui badan peradilan}

Sesuai dengan peraturan yang berlaku di Indonesia, pada umumnya penyelesaian sengketa pertanahan yang terkait sengketa kepemilikan diserahkan ke peradilan umum, terhadap sengketa keputusan Badan Pertanahan Nasional melalui Peradilan Tata Usaha Negara dan sengketa menyangkut tanah wakaf diajukan ke Peradilan Agama. 


\section{Kendala Yang Dihadapai Kantor Pertanahan Kabupaten Lombok Tengah Dalam Menanggulangi Sertifikat Ganda}

Bila dikaitkan dalam ketentuan Pasal 32 ayat (1) Peraturan Pemerintah Nomor 24 Tahun 1997, maka sertipikat hak atas tanah sebagai alatbukti yang kuat merupakan alat bukti autentik yang mempunyai kekuatanpembuktian yang sempurna karena penerbitan sertipikat hak atas tanah telahmelalui proses yang panjang dimana bagi pihak yang telah merasa memiliki hakatas tanah tersebut dapat mengajukan keberatan dengan data yuridis selamajangka waktu yang telah ditentukan.

Sertifikat diberikan bagi tanahtanah yang sudah ada surat ukurnya ataupun tanah-tanah yang sudah diselenggarakan Pengukuran Desa demi Desa, karenanya sertifikat merupakan pembuktian yang kuat, baik subyek maupun obyek ilmu hak atas tanah. Sertipikat memberikan kekuatan pembuktian bagi pemilik hak atas tanah yang namanya tercantum dalam sertipikat, kecuali adanya cacad data fisik maka kekuatan hukum sertipikat akan hilang. Dengan adanya cacad yuridis dan cacad data fisik sehingga dapat menimbulkan sertipikat ganda hal ini terjadi pada sertipikat yang tidak dipetakan dengan tidak benardi dalam peta pendaftaran tanah oleh Kantor Pertanahan setempat. Munculnya sertipikat ganda biasanya timbul karena para pihak selaku pemilik hak atas tanah melakukan pengaduan dan keberatan sebagai pihak yang dirugikan dengan munculnya sertipikat pada obyek yang sama dengan nomor yang sama tetapi pengeluaran tanggal yang berbeda tahun, sedangkan untuk surat ukur/gambar situasi dengan nomor dan tanggal yang sama, serta luas tanah yang sama.

Maksud dilakukan keberatan dan pengaduan tersebut agar pemilik hakatas tanah mendapatkan penyelesaian secara administrasi dengan apa yangdisebut koreksi dari Pejabat Tata Usaha Negara karena pemilik hak atas tanah merasa kepentingannya dirugikan. Kewenangan untuk melakukan koreksi ini berada pada Kepala Kantor Pertanahan tersebut sesuai dengan Peraturan Menteri Agraria/Kepala Badan Pertanahan Nasional Nomor 9 Tahun 1999, pelimpahan kewenangan kepada Kepala Badan Pertanahan Nasional mengenaipembatalan keputusan pemberian hak atas tanah dengan terbitnya sertipikat ganda sehingga terjadi cacad hukum dalam penerbitan sertipikat ganda tersebut. Pembatalan hak atas tanah dapat dilakukan karena adanya cacad administrasi salah satunya tumpang tindih hak atas tanah atau disebut sertipikat ganda. Permohonan pembatalan dengan adanya cacad hukum administrasi dapat diajukan oleh pihak yang berkepentingan yaitu pemilik hak atas tanah dengan mengajukan permohonan tertulis yang ditujukan kepada Kepala Kantor Pertanahan yang bersangkutan.

Oleh sebab itu, dapat dikatakan bahwa dengan munculnya sertipikat ganda, maka kedudukan sertipikat ganda harus ditinjau ulang karena tidak mungkin kedua sertifikat itu dapat berlaku. Terdapat cacat hukum dalam sertipikat ganda ini, dalam hal ini kita melihat bahwa prinsip yang diambil adalah agar berbeda daripada apa yang biasanya terjadi dengan penerbitan dari sertipikat ganda atas satu bidang tanah diterbitkan 2 (dua) sertipikat. Dalam hal terjadinya sertipikat ganda, biasa dinyatakan bahwa sertipikat yang diterbitkan lebih dahulu adalah yang sah, sedangkan yang diterbitkan kemudian adalah yang tidak mempunyai kekuatan hukum. Kantor Pertanahan selaku instansi yang menerbitkan harus benar-benar menelusuri adanya cacat hukum yang bisa timbul yang diakibatkan oleh instansi tersebut, sehingga tidak merugikan para pemilik hak atas tanah. Pasal 1 huruf $b$ Keputusan Menteri Negara Agraria/Kepala Badan Pertanahan Nasional Nomor 10 Tahun 1993 Tentang Tata Cara Penggantian Sertipikat Hak Atas Tanah mendefinisikan sertipikat lama sebagai berikut :

"Sertipikat lama adalah sertipikat yang telah diterbitkan oleh Kantor Pendaftaran Tanah, Kantor Pendaftaran dan Pengawasan Pendaftaran Tanah, Kantor Sub Direktorat Agraria, Kantor Agraria dan Kantor Pertanahan 
Kabupaten/Kotamadya sebelum ditetapkannya Keputusan Kepala Badan Pertanahan Nasional Nomor 14 Tahun 1989".

Sedangkan definisi sertipikat baru menurut Pasal 1 huruf c Keputusan Menteri Negara Agraria/Kepala Badan Pertanahan Nasional Nomor 10 Tahun 1993 Tentang Tata Cara Penggantian Sertipikat Hak AtasTanah mendefinisikan sertipikat lama sebagai berikut :

"Sertipikat baru adalah sertipikat yang telah diterbitkan oleh Kantor Pertanahan Kabupaten/Kotamadya dengan menggunakan blanko sertipikat sebagaimana ditetapkan dengan Keputusan Kepala Badan Pertanahan Nasional Nomor 14 Tahun 1989".

Ada beberapa akibat yang ditimbulkan dari adanya sertifikat ganda yakni :

\section{a. Terjadi kekacauan kepemilikan}

Dengan adanya sertifikat ganda, tentunya menimbulkan ketidakjelasan terhadap siapa pemilik asli sertifikat tersebut dan masing-masing akan mengklaim kepemilikan sertifikat hak atas tanahnya, termasuk kekacauan data yang ada pada kantor pertanahan.

\section{b. Terjadi sengketa hukum pertanahan}

Pengertian sengketa pertanahan dirumuskan dalam Pasal 1 Peraturan Menteri Negara Agraria/Kepala Badan Pertanahan Nasional Nomor 1 tahun 1999 tentang Tata Cara Penanganan Sengketa Pertanahan, selanjutnya disebut PMNA/KBPN 1/1999, yaitu :

“ perbedaan pendapat antara pihak yang berkepentingan mengenai keabsahan suatu hak, pemberian hak atas tanah, pendaftaran hak atas tanah, termasuk peralihan dan penerbitan tanda bukti haknya serta pihak yang berkepentingan yang merasa mempunyai hubungan hukum dan pihak lain yang berkepentingan terpengaruh oleh status hukum tanah tersebut”.
Dari pengertian tersebut, dapat dikatakan bahwa dengan timbulnya sertifikat ganda, maka terjadi sengketa hukum yang diakibatkan karna adanya penerbitan dua sertifikat yang sama dengan pemilik yang berbeda sehingga keabsahan salah satu sertifikat dipertanyakan.

\section{c. Terjadi ketidak pastian hukum}

Sebagaimana yang penulis jelaskan pada BAB I, Bahwa hukum bertugas menjamin adanya kepastian hukum (rechszekerheid) dalam pergaulan manusia. Dalam tugas itu tersimpul dua tugas lain, yaitu harus menjamin keadilan serta hukum tetap berguna. Kepastian hukum dapat menjadi alat untuk memberikan rasa aman karena setiap peristiwa dan keadilan memiliki dasar hukum yang konkrit dan jelas. Dalam kasus sertifikat ganda, karna ada dua sertifikat yang dikeluarkan oleh kantor pertanahan setempat, maka hal tersebut tentu menimbulkan ketidak pastian hukum siapa pemilik sah atas hak milik atas tanah yang dimaksud. Sehingga menimbulkan sengketa antara keduabelah pihak.

d. Terjadi tindak pidana atas pemakaian sertifikat yang palsu yang merugikan pemilik sertifikat asli ataupun pihak lainnya

Dengan adanya sertifikat ganda, maka tentu salah satu pihak bisa saja kemudian menjual tanah tersebut atau hendak menjadikan jaminan sertifikat tanah tersebut dengan cara melawan hukum sehingga dapat di indikasikan adanya tidak pidana penipuan terhadap pihak ketiga (diluar pemilik sertifikat ganda) dan menimbulkan sengketa berlarut antara pemegang sah hak atas tanah dengan pihak ketiga tersebut.

e. Ketidak percayaan masyarakat terhadap sertifikat

Karena kesalahan dalam penerbitan sertifikat yang berakibat adanya sertifikat ganda, sehingga menimbulkan ketidak pastian hukum dan menimbulkan sengketa tanah, maka tidak menutup kemungkinan masyarakat enggan melakukan pendaftaran hak atas tanahnya pada 
kantor pertanahan setempat dan lebih memilik untuk menggarap tanahnya tanpa alas hak bahkan lebih memilih menjual tanahnya tanpa ada sertifikat hak atas tanah sehingga menurunkan nilai ekonomis dari tanah tersebut.

Dalam beberapa sengketa yang terjadi atas sertifikat ganda yang ada di Lombok Tengah, yang menimbulkan sengketa diantara para pihak, karena masing-masing pihak mengatakan bahwa sertipikatnyalah yang sah, sedangkan sertipikat yang lain tidak sah dan harus dibatalkan. Dalam keadaan seperti inilah diuji kekuatan pembuktian sertipikat dan kekuatan sertipikat dalam memberi perlindungan hukum terhadap pemegang sertipikat tersebut. Para pihak harus dapat membuktikan bahwa dia adalah pihak yang berhak dengan mengajukan bukti-bukti yang akan dinilai oleh hakim. Sistem publikasi pendaftaran tanah yang dianut oleh Peraturan Pemerintah Nomor 24 Tahun 1997 adalah sistem publikasi negatif mengandung unsur positif, yaitu sertipikat hanya sebagai alat bukti yang kuat, dimana masih terbuka kesempatan bagi pihak yang merasa dirugikan untuk mengajukan gugatan ke Pengadilan mengenai penguasaan tanah atau penerbitan sertipikat tersebut, atau dengan kata lain, jika kemudian telah diterbitkan sertifikat hak atas tanah (sertifikat pertama), dikemudian hari terjadi kesalahan atau suatu tindakan tertentu yang menyebabkan terbitnya sertifikat ganda (sertifikat kedua) atas nama pihak lain, maka pihak pertama (pemegang sah hak atas tanah) dapat mengajukan gugatan ke pengadilan untuk melakukan pembatalan atas terbitnya sertifikat tanah kedua tersebut.

Terhadap upaya yang telah dilaksanakan oleh pihak BPN Lombok Tengah dalam penyelesaian sengketa sertifikat ganda di Lombok Tengah, masih ditemui beberapa kendala yang menghambat proses penyelesaian sengketa sertifikat ganda tersebut diantaranya :

\section{a. Kebenaran Data}

Akibat adanya ketidak sesuaian data yang diberikan oleh para pihak dimana para pihak sebelumnya telah sama-sama membuktikan dirinya berhak, maka pihak BPN membutuhkan waktu yang sangat lama untuk melakukan perivikasi berkas kedua sertifikat ganda tersebut mulai dari melakukan pengukuran ulang, mengecek kesesuaian berkas, hingga proses putusan pengadilan tetap jika kedua belah pihak ternyata sudah membawa kasus tersebut pada ranah pengadilan. Selain itu pula, pemegang sah hak atas tanah terkadang kehilangan sertifkatnya dan hanya memiliki fotocopy saja, sementara data sertifikat asli yang dimiliki merupakan sertifikat yang diterbitkan sekitar tahun goan dimana data pada saat itu masih di Input dalam bentuk manual sehingga menyulitkan pihak BPN dalam melakukan perivikasi data.

\section{b. Masalah Yang Berlarut}

Tidak jarang pihak BPN Lombok Tengah merasa sangat keuslitan untuk mengajak para pihak melakukan mediasi karena masalah yang berlanjut. Pihak yang bersengketa sama-sama keras dan tidak ingin menyelsaikan dengan cara musyawarah mufakat. Sehingga ketika pihak BPN ingin melakukan mediasi, para pihak lebih memilih melalui jalur pengadilan daripada mediasi yang lebih cepat dan murah.

Oleh sebab itu, semenjak tahun 2010, BPN seluruh Indonesia sudah memulai melakukan pendataan dengan menggunakan data digital sehingga kemungkinan terjadi sertifikat ganda sangat kecil. Selain itu pula, BPN melakukan perluasan kewenangan dengan menjadi mediator manakala terjadi sertifikat ganda maupun sengketa pertanahan lainnya.

\section{Kesimpulan dan Saran 1. Kesimpulan}

a. Adapun strategi yang dilakukan Kantor Pertanahan Kabupaten Lombok Tengah dalam menanggulangi sertifikat ganda diantaranya adalah menelaah dan mengelolah data perkara di bidang pertanahan, menampung gugatangugatan, menyiapkan bahan memori jawaban, menyiapkan memori banding, memori/kontra memori kasasi, memori/kontra memori peninjauan kasasi atas perkara yang diajukan melalui peradilan terhadap 
perorangan dan badan hukum yang merugikan negara, mengumpulkan data masalah dan sengketa pertanahan, menelaah dan menyiapkan konsep keputusan mengenai penyelesaian sengketa atas tanah serta menelaah dan menyiapkan konsep keputusan pembatalan hak atas tanah yang cacat administrasi dan berdasarkan kekuatan putusan peradilan.

b. Ada beberapa hambatan yang dihadapi oleh Kantor Pertanahan Kabupaten Lombok Tengah dalam menanggulai persoalan sertifikat ganda yakni :

1) Masalah kebenaran data yang harus dibuktikan oleh BPN terhadap sertifikat ganda mengingat serifikat yang disengketakan adalah sertifikat yang berasala dari tahun goan sehingga data yang dimiliki oleh pihak BPN belum masuk dalam data digital.

2) konflik yang berlarut mengakibatkan kedua belah pihak tidak mau menyelesaikan secara sederhana sehingga pihak BPN sulit mengajak kedua belah pihak untuk melakukan mediasi.

\section{Saran}

a. Hendaknya pejabat Kantor Pertanahan Lombok Tengah lebih meningkatkan upaya pencegahan penerbitan sertipikat ganda ataupun sengketa-sengketa tanah lainnya, dan dilakukan sejak awal dengan melakukan pendaftaran tanah dengan lebih teliti, cermat dan seksama, dan melengkapi peta-peta pendaftaran tanah diwilayah yang bersangkutan.

b. Perlu adanya penegakan hukum bagi pejabat yang menerbitkan sertifikat ganda sehingga adanya upaya hukum yang kongkrit bagi pejabat tersebut untuk tidak lagi secara melawan hukum menerbitkan sertifikat ganda.

\section{Daftar Pustaka}

\section{buku dan artikel}

Ali Achmad Chomzah, 2003. Hukum Pertanahan Seri Hukum Pertanahan III-Penyelesaian Sengketa Hak Atas Tanah dan Seri Hukum Pertanahan IV-Pengadaan Tanah Instansi Pemerintah, Jakarta, Prestasi Pustaka.

Ali Ahmad Comzah. 2004. Hukum Agraria (Pertanahan Di Indonesia). Jakarta. Perestasi. Pusakarya.

AP. Parlindungan, 1991. Pendaftaran tanah di indonesia, Mandar Maju, Bandung.

Harsono Boedi, 1994. Hukum Agraria Indonesia: Sejarah Pembentukan Undang-Undang Pokok Agraria, Isi dan Pelaksanaanya, Jilid 1, Djambatan, Jakarta.

Hutabarat Jemsly \& Martani Huseini. 2006. Pengantar Manajemen Strategik Kontemporer, Strategik di Tengah Operasional. Jakarta : PT. Elex Media Komputindo

Maladi Yanis, 2008. Pendaftaran Tanah Nasional dan Kehidupan Hukum Masyarakat (Perspektif Teori-teori Sosial), Mahkota Kata, Yogyakarta.

Pasolong, Harbani. 2008. Teori Administrasi Publik. Bandung : Alfabeta

Purwanto, Iwan. 2007. Manajemen Strategi. Bandung : Yrama Widya

Rangkuti, Freddy. 1997. Analisis SWOT Teknik Membedah Kasus Bisnis. Jakarta : PT. Gramedia Pustaka Utama.

Sinambela, Lijan P dkk. 2006. Reformasi Pelayanan Publik : Teori, Kebijakan dan Implementasi.Jakarta : Bumi Aksara

Soerjono Soekamto, Sri Mamuji, 1985. Penelitian Hukum Normatif Suatu Tujuan Singkat, Penerbit CV. Rajawali, Jakarta

Soerjono Soekanto, 1986. Pengantar Penelitian Hukum, Jakarta : UI Press.

Susanto, AB. 2014. Manajemen Komprehensif Strategik Untuk Mahasiswa Dan Praktisi. Jakarta : Erlangga

Tjiptono, Fandy. 1997. Strategi Manajemen Pemasaran. Yogyakarta

Yogi. 2007. Manajemen Strategi Terapan pandua Cara Menganalisa Industri dan Pesaing. Jakarta : Poliyama.

Boedi Harsono, 2005. Hukum Agraria Indonesia, Sejarah Pembentukan UUPA, Isi Dan Pelaksanaannya, Jakarta; Djambatan.

Purnadi Purbacaraka Dan Ridwan Halim, 1985. Sendi-Sendi Hukum Agraria, Jakarta Timur: Ghalia Indonesia.

Effendi Perangin, 1989. Hukum Agraria Di Indonesia, Jakarta: Grafikatama.

Ali Chomzah, 2000. Hukum Pertanahan Seri I Hukum Pertanahan Pemberian Hak Atas Tanah Negara Dan Seri II Sertipikat Dan Permasalahannya, Cet. 1. Rineka Cipta. Jakarta.

Utoyo Sutopo, 1992. Konflik Tanah Dalam Era Modern. Gratama, Yogyakarta.

\section{Peraturan Perundang-undangan}

Indonesia, Undang-Undang Dasar Negara Republik Indonesia Tahun 1945

Indonesia, Undang-undang Nomor 5 Tahun 1960 (Lembaran Negara Tahun 1960 Nomor 104, Tambahan Lembar Negara Republik Indonesia Nomor 2034), tentang Peraturan Dasar Pokok-Pokok Agraria. 
Indonesia. Peraturan Pemerintah Nomor 24 Tahun 1997 Tentang Pendaftaran Tanah 